\title{
FINANCIAL SECTOR LIBERALISATION AND AGRICULTURAL SECTOR OUTPUT: FRESH EVIDENCE FROM NIGERIA
}

\author{
Author \\ Ugah John \\ https://orcid.org/0000-0003-2145-5832 \\ Research Student, Department of Banking and Finance, Faculty of Management Sciences, University of \\ Calabar, Nigeria. \\ Email: ugahson@gmail.com
}

\begin{abstract}
This study examined the relationship between financial sector liberalization and agricultural sector output in Nigeria using annual data spanning the period 1986-2020. Specifically, the objectives of the study are to examine the relationship between lending rate, exchange rate, commercial bank credit to agriculture, inflation rate and agricultural sector output in Nigeria. Ex-post facto research design was employed, and the annual time series data were collated from Central Bank of Nigeria $(\mathrm{CBN})$ Statistical Bulletin. The econometrics methods of unit root, co-integration and error correction mechanism were used for the analyses. The outcome of the ADF unit root test show that the variables were stationary. Also, the co-integration result showed that there exist cointegration amongst the variables in the model. The results from Error Correction Model indicates that lending rate and inflation rate have a negative relationship on agricultural sector output while exchange rate and commercial bank credit to agriculture have positive relationship on agricultural sector output. Based on these results, this study recommends that government and policy makers in Nigerian should initial policies that will boost investments in the agricultural sector through direct provision of credits to agriculturist and banks should also lend at a very low and subsidized interest rate to enable farmers' access agricultural loans that will boost agricultural productivity in the economy.
\end{abstract}

Keywords: Financial Liberalization, Agriculture Output, Lending Rate, Inflation Rate, Exchange Rate, Commercial bank credit

\subsection{Introduction}

It is almost impossible to ignore the importance of the agriculture sector in any economy because of its crucial role in combating poverty and achieving long-term economic development. Udeaja, \& Udoh, (2014) asserted that the agriculture sector remains the foundation of economic growth and development. Unarguably, the agriculture sector will continue to exist as a prominent sector in the Nigerian economy because of its indispensable role played in the provision food, clothing, 
raw materials and other agro-products for the citizenry. Agriculture contribution to GDP was the leading economic sector from 1960 to 1970, contributing more than 50 percent to real GDP during the period (CBN, 2004). According to Uniamikogbo \& Enoma (2001), this was the biggest economic activity when compared with productivity shares of other sectors during the periods. However, with oil discovery and the oil boom of the 1970s, the sector suffered neglect.

Figure 1: Agricultural contribution to Real Gross Domestic Product (1960-2020)

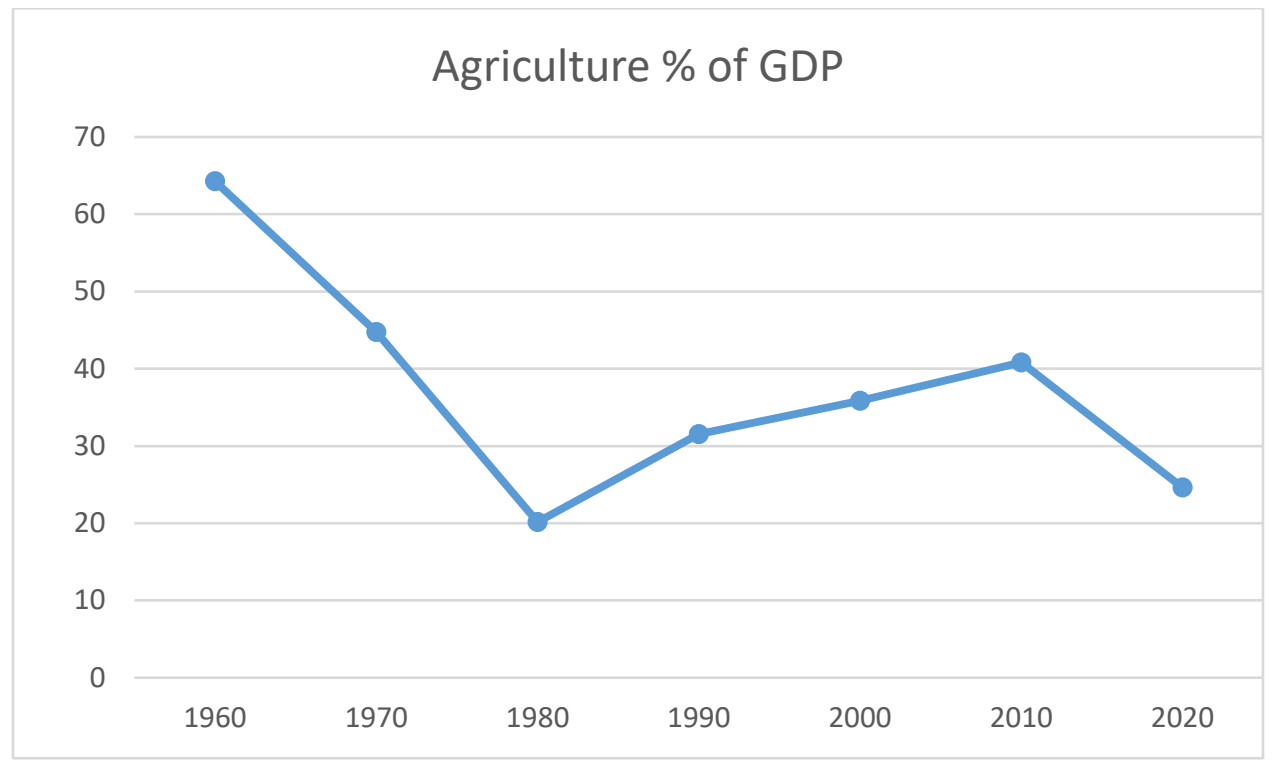

Source: Central Bank of Nigeria Statistical Bulletin, 2020

As shown in figure 1 above, agriculture was the leading economic sector from 1960 to 1970, contributing 64.3 per cent to real GDP in 1960. Albeit beginning from 1970, the role of agriculture as key drivers of growth in the economy diminished to 44.7 per cent and by 1980, agriculture contribution to real GDP had fallen drastically to 20.6 per cent. However, the agricultural sector resuscitated, following the implementation of the Structural Adjustment Programme (SAP) in 1986, with an upsurge in agriculture contribution to real GDP from 31.5 per cent in 1990 to 35.8 per cent in 2000 and further to 40.8 per cent in 2010 but declined to 24.61 per cent in 2020 due to the impact of Covid- 19 pandemic leading to food insecurity, increase in price levels and increased level of poverty in the country with the poverty level standing at 40 per cent in 2020 (NBS, 2020).

Due to the failing agricultural sector, Nigeria following the footprints of most developing economies, adopted various forms of policies and institutional reforms in boosting the economic development as well agricultural sector output (Udah \& Obafemi, 2011). These range from 
protectionism, restrictions and excessive government control of economic activity to the movement towards free market economy hence financial liberalization.

Financial liberalisation is the removal of controls by the regulatory authorities in a nation, thereby deregulating the financial system (Okuma, 2019). As observed by Francis \& Kallummal (2009), the main attributes of financial liberalisation includes: deregulation of interest rates; removal of control on credits; liberalisation of entry restrictions in the financial sectors; and the liberalisation of international capital flows or capital account liberalisation. Thus, the essence of financial liberalisation in any economy is to liberalise interest rates, remove credits control, promote competition in the market through the operation of the invisible hand, strengthening the regulatory institutions and deepening of the financial sector (with the agricultural sector inclusive).

Since the emergence of the concept of financial liberalization in the 1970s, some countries across the continents (such as China, Turkey, Indonesia, Angola, India, Gambia, Kenya's, Mozambique, Nigeria etc) have made attempt at liberalizing their financial sectors by deregulating interest rates, reducing credit controls, removing barriers on market entry into the financial sector, permitting private ownership of banks and liberalizing international capital flows (Onwumere, Okoro, \& Imo, 2012).

In Nigeria, the process of financial liberalisation begins with the introduction of Structural Adjustment Programme (SAP) in 1986 in the country. However, prior to the introduction of SAP, the Nigerian economy witnessed stringent and excessive government interference in control of production, financial intermediation processes and foreign trade variables through the determination of interest rates, prices and exchange rates (Udah \& Obafemi, 2011). Until the emergence of SAP, credit and deposit functions of financial institutions in Nigeria were deemed abysmal. Notably, there has been poor allocation of financial credit to the agriculture sector (Quartey, Udry, Alhassan and Seshie, 2012).

For most developing countries, agriculture is a crucial to economic growth and development (Camillus, 2019). This is not evidenced in Nigeria as the agricultural sector is bedevilled with several emerging problems which limits the sector full realization of its full potentials (Onoja, 2017). Among the problems include strict government regulations and inconsistent government policies, restrictions of credit to agricultural sectors, high interest rates and exchange rates etc. Most of these problems could be solved if appropriate financial sector liberalisation strategies are put in place. As a policy response to address these problem, SAP was promulgated in 1986 to 
reduce the adverse effects policies which the proponent of aggressive economic interference (government) had on economic performance and to allow efficiency in market operations and also to reduce the myriad of problems bombarding the financial sector and other key sectors (esp. agricultural sector) in the economy (Ehinomen \& Akorah 2013).

It is evident that despite notable policies to mitigate losses arising from the Nigerian agricultural sector and reforms to aid financial development, no improvement on economic growth and poverty remains inherent for many years. However, a seminar work of MCkinnon and Shaw (1973) concludes that financial liberalization is the only way forward in an economy especially a developing economy like Nigeria. This is contrary to Keynes, Tobin and Stinglitz (1989) who advocated government interference (financial repression) in the financial market. The argument for this study is whether financial sector liberalization impact on agricultural sector output in Nigeria. It is on this note that this study examine the relationship between financial sector liberalisation and agricultural sector output in Nigeria. Specifically, the paper sought to examine the relationship between lending rate, exchange rate, commercial bank credit to agriculture, inflation rate and agricultural sector output in Nigeria.

\subsection{Theoretical framework: Financial development theory}

Financial development theory is credited to the work of Shaw and McKinnon in 1973. The theory states that financial liberalisation can exert a positive effect on growth rate as interest rates and exchange rates level rise towards market equilibrium when resources are efficiently distributed. Shaw (1973) and McKinnon (1973), posits that positive real deposit rates raise the saving rate; increase financial deepening; raise investment and thus growth. The theory was developed to examine the relationship between economic growth and financial development'. In doing this, they hypothesised two leading hypotheses; the "demand leading", which posits that financial development accrete as the economy improves; and a "supply-leading" phenomenon, in which the general growth of financial institutions leads to an economic increase. Thus, financial development is a function of economic growth with respect to demand of financial services and vice versa (Patrick, 1966). For Mckinnon (1973) financial development through liberalization lead to unified financial markets and the best strategy is to let interest rates and exchange rate freely fluctuate (Kisaka, Adhianbo, Hdegeand, \& Muio, 2015). The efficacy of the financial development theory is a predicament on some leading finance oriented reforms like the financial liberalization. The theory is suitable for the study because it assert that through financial liberalisation, the agricultural 
sector can increase output, if the regulatory authorities allow financial institutions operate smoothly by the invisible hand.

\subsection{Empirical review}

Most empirical studies on financial liberalization centered on the growth of the overall economy. This study, however focuses on the agricultural sector because empirical studies carried out on financial liberalisation and agricultural sector output are scanty.

Under this review, Adongo, John, Zeph \& Muyima (2020) investigated the impacts of monetary policy on the Agricultural gross domestic product in Kenya. Secondary annual time series data were used for the period of 37 years (1981 to 2019). The unit root test, Johansen Co-integration test and the ordinary least square (OLS) regression technique were used to analyse the data. The OLS results revealed that broad money supply has a positive impact on agricultural GDP while exchange rate has a negative impact on agricultural GDP. Overall, the study concluded that there exist a long run relationship between monetary policy and agricultural sector GDP in Kenya. Oteng-Abayie, Yusif \& Ussif, (2019) investigated the effect of financial development on agriculture output growth in Ghana for the period 1980 to 2014. Time series data for agriculture machinery and tractors per agriculture land was used in the investigation. The study employed ARDL cointegration analysis to examine the short-run and long-run relationships between the measures of financial development (money supply and credit to the private sector) and agriculture output growth in a Cobb-Douglas production framework which captured agriculture capital and rural labour inputs as determinants of agriculture output growth. The results showed that in the case of Ghana, financial development has an insignificant effect on agriculture output growth both in the short and long runs.

Camillus (2019) examined the causal relationship between financial liberalization and agricultural sector output in Nigeria (AOG). Ex-post facto research design was employed. Annual time series data obtained from Central Bank of Nigeria (CBN) Statistical Bulletin were employed with the unit root test, Engel co-integration test, error correction model and Granger causality test for analyses. Prime Lending Rate, Deposit Rate, Exchange Rate, Money Supply as percentage of Gross Domestic Product and Liquidity Ratio are used as indicators of financial liberalization. Hence the study concluded that AOG leads financial liberalization in Nigeria. Using similar research design and methodology, Camillus (2019) also examined the causal relationship between financial deepening and agricultural sector output in Nigeria (AOG). Here, financial deepening 
was proxied by prime lending rate, deposit rate, ratio of financial savings to GDP, ratio of private sector credit to GDP, ratio of money supply to GDP. The result of Granger Causality showed that AOG, granger causes PLR, RFS, RPSC, RMS indicating evidence of demand following hypothesis (AOG leads financial deepening).

Furthermore, Onoja (2017), evaluated the relationship between financial sector development and agricultural productivity. To empirically investigate the linkage between agricultural productivity and financial sector development, a cross country panel data from 75 developing countries were collated and analysed using the panel fixed effects econometrics approach. Results from the analysis shows that financial sector development has a positive effect on agricultural productivity but was found to be statistically insignificant. While, agricultural credit has a positive and significant effect on productivity across sample of 75 developing countries. Additionally, Tuaneh, \& Ewubare (2016) conducted a study to examine the effect of financial deepening on agricultural contribution to GDP in Nigeria (1981-2014) using secondary data sourced from CBN statistical bulletin. The data were subjected to stationarity and co-integration test before using multiple regression analysis. The causal links between the pairs of explanatory variables of interest and the criterion variable were established using the multiple regression. The test of significance revealed that; Money Supply as a Ratio of GDP and Credit to the Private Sector as a Ratio of GDP significantly affect Agriculture's Contribution to GDP, Crop Contribution to GDP, and Livestock Contribution to Gross Domestic Product.

Udeaja, \& Udoh, (2014) empirically investigated the effect of monetary policy on agricultural sector in Nigeria from 1970 to 2010. The independent variables used was lending rate, commercial banks credit to agriculture, exchange rate, government expenditure in agriculture and inflation rate while the dependent variable was agricultural output. The Auto- Regressive Distributed Lag (ARDL) Bound Testing was used to analyse the secondary data obtained for the period. The results revealed that only exchange rate and government expenditure had positive and significant effect on agricultural output. It is therefore recommends that suitable exchange rate policy capable of abetting agricultural export in Nigeria should be implemented to improve agricultural output in Nigeria.

It is evidenced from the empirical study that studies that focus on financial liberalization and agricultural sector output in Nigeria are scanty. Also, none of the previous works studied 
empirically covered time frame and scope up to 2020. Thus this study intends to provide fresh evidence on the topic and buttressed existing literatures.

\subsection{Materials and methods}

The research adopts the ex-post facto research design. This type of research is undertaken after the events have taken places and the data are already in existence. The study also employed annual time series data collated from 1986-2020. The data relevant for the study was obtained from the Central Bank of Nigeria Statistical Bulletin and the Nigerian Bureau of Statistics (NBS). The study employed the residual diagnostic test, correlation analysis, unit root test, co-integration and error correction mechanism methods for the analysis.

\section{Model Specification}

Based on this theoretical exposition and in line with Udeaja, \& Udoh, (2014), the following empirical model was formulated to guide the study:

$\mathrm{AGOUT}=f(\mathrm{LEN}, \mathrm{EXCH}, \mathrm{CBCA} \mathrm{INF})$

Thus, the econometric model of this study is:

$\mathrm{AGOUT}=\beta_{0}+\beta_{1} \mathrm{LEN}+\beta_{2} \mathrm{EXCH}+\beta_{3} \mathrm{CBCA}+\beta_{4} \mathrm{INF}+\mathrm{e}$

Where:

AGOUT $=$ Agricultural GDP

LEN = Lending Rate;

$\mathrm{EXCH}=$ Exchange Rate

$\mathrm{CBCA}=$ Commercial Banks Credit to Agriculture; $\quad$ INF = Inflation Rate

$\mathrm{B}_{0} \quad=$ Interception; $\beta_{1}-\beta_{3}=$ Slope coefficient; $\mathrm{e}=$ Error term. 
Definition of variables and A priori expectation

\begin{tabular}{|c|c|c|}
\hline Variable & Definition & A priori Expectation \\
\hline AGOUT & $\begin{array}{l}\text { The contribution of agriculture to total } \\
\text { real GDP measured in billions of naira }\end{array}$ & \\
\hline LEN & $\begin{array}{l}\text { The nominal cost of borrowing money } \\
\text { expressed in percentage }\end{array}$ & - \\
\hline $\mathrm{EXCH}$ & $\begin{array}{l}\text { The value of one country's currency } \\
\text { relative to that of another country. }\end{array}$ & $+/-$ \\
\hline CBCA & $\begin{array}{l}\text { The value of commercial banks' credit to } \\
\text { agriculture measured in billions of naira }\end{array}$ & + \\
\hline INF & $\begin{array}{l}\text { The percentage of change in price levels } \\
\text { of goods and services }\end{array}$ & - \\
\hline
\end{tabular}

\subsection{Result and Discussion}

\subsection{Descriptive statistics}

The trend behaviour of the data set in the appendix are presented in the descriptive statistics analysis as shown in Table 4.1 .

TABLE 4.1

Result of descriptive statistics

\begin{tabular}{lccccc}
\hline & AGOUT & LEN & EXCH & CBCA & INF \\
\hline Mean & 7955.55 & 18.6231 & 108.012 & 153.070 & 20.5200 \\
Median & 4418.72 & 17.7678 & 119.768 & 52.6197 & 12.4100 \\
Maximum & 31904.1 & 29.8000 & 306.920 & 610.149 & 76.7600 \\
Minimum & 35.7026 & 10.5000 & 2.02057 & 1.83030 & 3.61000 \\
Std. Dev. & 6117.23 & 3.72728 & 91.7081 & 197.797 & 18.2930 \\
Observations & 35 & 35 & 35 & 35 & 35 \\
\hline
\end{tabular}

Source: E-views 11.0 statistical software

The result of the descriptive statistics presented in Table 4.1 depicted that, agricultural output proxied for agricultural contribution to GDP stood at an average mean of 7955.55, for the thirty five (35) year period. This positive value of AGOUT implies that agricultural contribution to GDP in Nigeria was positive. The standard deviation stood at 6117.23. This demonstrated that the 
AGOUT was stable and did not deviate too much from the mean. The value of lending rates (LEN) shows its minimum value as 10.5000 in 1986 and maximum of 29.8000 in 1992; with a mean value and standard deviation of 18.6231 and 3.72728 respectively. Further the descriptive statistics revealed that the mean value of $\mathrm{EXCH}$ was 108.012 for the same period with its standard deviation of 91.7081. This demonstrated that the exchange rate was fairly stable and did not deviate too much from the mean. Again the analysis showed that commercial bank credit to agriculture (CBCA) stood at an average of 153.070 with a standard deviation of 197.797. Finally, the inflation rate (INF) revealed its mean value as 20.5200 with a standard deviation of 18.2930 having its minimum value as 3.61000 in 1990 and its maximum value of 76.7600 in 1994 .

\subsection{Residual Diagnostic Test Results}

To ensure robustness and reliability in the parameter estimates, the study conducts some diagnostic and reliability tests. The results of the residual diagnostic tests for Breusch-Godfrey serial correlation LM test, Breusch-Pagan-Godfrey heteroskedasticity test, Jarque-Bera normality test and CUSUM stability test are presented on Table 2.

Table 2

\section{Residual Diagnostic Test Results}

\begin{tabular}{lll}
\hline Diagnostics tests & Observed values & P-values \\
\hline Breusch-Godfrey Serial Correlation LM Test & 24.89006 & 0.0000 \\
Jarque-Bera Normality Test & 0.357330 & 0.8363 \\
Breusch-Pagan-Godfrey Heteroskedasticity Test & 5.591828 & 0.1018 \\
Stability diagnostic test & Stable & Stable \\
\hline
\end{tabular}

Source: E-views 11.0 statistical software

The result of the diagnostic residual tests showed that the model was free from serial correlation because the Breusch-Godfrey serial correlation LM test accepted the null hypothesis of no serial correlation in the residual since the probability of the observed R squared is less than the 5\% level. Similarly, the Jarque-Bera normality test and the Breusch-Pagan-Godfrey Heteroskedasticity test both had their probability values to be greater than the $5 \%$ level, indicating that the model was normally distributed and free from heteroskedasticity, respectively. In addition, the result of the CUSUM test on Figure 2 (see appendix) had plots all within the two straight line showing that the model was stable. 


\subsection{Pearson Correlation}

In an effort to analyze the nature of the correlation between the dependent and the independent variables and to examine the possible degree of association among the variable, a pairwise correlation analysis have been computed and summarize in Table 3

Table 3

\section{Correlation Results}

\begin{tabular}{llllll}
\hline & AGOUT & LEN & EXCH & CBCA & INF \\
\hline \hline AGOUT & 1.0000 & & & & \\
LEN & -0.3794 & 1.0000 & & & \\
EXCH & 0.7354 & -0.3121 & 1.0000 & & \\
CBCA & 0.7671 & -0.3499 & 0.8883 & 1.0000 & \\
INF & -0.3811 & 0.3373 & -0.4324 & -0.3238 & 1.0000 \\
\hline
\end{tabular}

Source: E-views 11 statistical software

The correlations results shows that AGOUT is significant and positively related with EXCH (0.7354) and CBCA (0.7671) all at 5\% significance level while LEN and INF shows negative correlation with AGOUT. From the correlation results, the relationship between AGOUT and the independent variables (except for lending rate and inflation rate) are strong and positive. These suggest that increase in each of these series will lead to corresponding increase in agricultural output in Nigeria.

\subsection{Unit Root Test}

Unit root test were conducted to ensure that the series were stationary and check the problem of having a spurious regression. For this study, test of stationarity of the variables was conducted using the augmented Dickey-Fuller (ADF) unit-root test.

Table 4

Augmented Dickey-Fuller - Unit Root Test

\begin{tabular}{llllll}
\hline Variables & \multicolumn{2}{c}{ ADF at Level } & ADF at First Difference & $\begin{array}{l}\text { Order of } \\
\text { integration }\end{array}$ \\
\hline & Test Stat & Prob & Test Stat & Prob & \\
\hline AGOUT & 9.608571 & 1.0000 & -6.389300 & $0.0000^{*}$ & $\mathrm{I}(1)$ \\
LEN & 4.538199 & 0.6710 & -5.216820 & $0.0002^{*}$ & $\mathrm{I}(1)$ \\
EXCH & 0.984054 & 0.9954 & -4.034113 & $0.0038^{*}$ & $\mathrm{I}(1)$ \\
CBCA & 2.698765 & 1.0000 & -6.566737 & $0.0000^{*}$ & $\mathrm{I}(1)$ \\
INF & 0.220857 & 0.0579 & -5.322212 & $0.0001^{*}$ & $\mathrm{I}(1)$ \\
\hline
\end{tabular}

Source: E-views 11.0 statistical software 
From the results in Table 4 (above) the unit root test results reveals that at level no variables were stationary. This is because the individual probability values of the variables are higher than the 5 per cent significance level, ergo the hypothesis of the variables cannot be rejected. However, all the variables become stationary after first difference, since their p-values are lesser than $5 \%$ which led to the rejection of the hypothesis of presence of unit root in the variables. This implies that all the variables under observation are cointegrated of the same order one that is I (1).

\subsection{Co-integration Test}

If the unit root test result conducted shows that all the modeled variables are integrated of same order one. It therefore gives economy credence for the study to apply the cointegration tests in order to examine the long-run relationships among the variables (Tilakaratna., 1996). The result of table 4 shows that all the variiables are cointegrated of the same order one that is I (1). Hence, Johansen co-integration test will be employed. The results of Johansen co-integration test for Trace statistic tests are reported in Table 5.

Table 5

Johansen Co-integration Test

Unrestricted Co-integration Rank Test (Trace)

\begin{tabular}{|c|c|c|c|c|}
\hline $\begin{array}{l}\text { Hypothesized No. } \\
\text { of CE(s) }\end{array}$ & Eigenvalue & $\begin{array}{l}0.05 \text { Critical } \\
\text { Value }\end{array}$ & t-statistics & Prob** \\
\hline None* & 0.769629 & 69.81889 & 99.99219 & 0.0000 \\
\hline At most $1^{*}$ & 0.559136 & 47.85613 & 53.01407 & 0.0152 \\
\hline At most 2 & 0.359926 & 29.79707 & 26.80547 & 0.1065 \\
\hline At most $3^{*}$ & 0.252133 & 15.49471 & 12.52796 & 0.0133 \\
\hline At most 4 & 0.096039 & 3.841465 & 3.230993 & 0.7423 \\
\hline
\end{tabular}

Source: E-views 11.0 statistical software

The results for trace rank tests indicate the presence of at least at least three cointegration vector at $5 \%$ level of significance. This result suggests that at least three cointegration vector exists among the dependent variables (AGOUT) and all the independent variables (LEN, EXCH, CBCA and INF). Therefore, the null hypothesis which states that there is no long run equilibrium relationship between the variables is rejected.

\subsection{Discussion and analysis of ECM results}

The result of the Johansen cointegration tests signifies that there exist a long run equilibrium relationships in the model. This give economic credence to carry out the error correction process taking into cognizance the different form of the various time series variables plus lag values of the error term from the static level equation (Engle and Granger, 1987). 
Table 6

ECM regression result

Dependent Variable: D(AGOUT)

Method: Least Squares

Date: 07/28/21 Time: 07:58

Sample (adjusted) : 19872020

Included observations: 34 after adjustments

\begin{tabular}{lcccc}
\hline Variable & Coefficient & Std. Error & t-Statistic & Prob. \\
\hline C & 7.301118 & 23.14036 & 3.155144 & 0.0039 \\
D(LEN) & -14.67944 & 45.43350 & -0.323097 & 0.7491 \\
D(EXCH) & 4.843123 & 10.53765 & 0.459602 & 0.6495 \\
D(CBCA $)$ & 9.409449 & 5.297264 & 1.776285 & 0.0870 \\
D(INF) & -2.122100 & 11.78673 & -0.180041 & 0.8585 \\
ECM (-1) & -0.201513 & 0.132816 & -1.517238 & 0.0408 \\
\hline \hline & 0.441897 & Mean dependent var & 965.7102 \\
R-squared & 0.270111 & S.D. dependent var & 1077.146 \\
Adjusted R-squared & 1086.269 & Akaike info criterion & 16.98185 \\
S.E. of regression & 31859456 & Schwarz criterion & 17.25394 \\
Sum squared resid & -274.2005 & Hannan-Quinn criter. & 17.07340 \\
Log likelihood & 0.892952 & Durbin-Watson stat & 0.659442 \\
F-statistic & 0.049984 & & \\
Prob(F-statistic) & &
\end{tabular}

Source: E-views 11.0 statistical software

The Error Correction Model (ECM) result the existence of autocorrelation was performed using Durbin-Watson statistic. The estimated DW-statistic is 0.65 , it can be deduced therefore, that there is no autocorrelation, in the error term and since the DW is less than 2, it suggests that the model is good for prediction. The R-squared value of 0.4418 indicated that the variation in AGOUT explained by lending rate (LEN), exchange rate $(\mathrm{EXCH})$, commercial bank credit to agriculture (CBCA) and inflation rate (INF) is 44 percent. Adjusted R-Squared with value 0.2701 indicates that the 27 percent of the changes that occur in the AGOUT are influenced by the changes in the independent variables. LEN, EXCH, CBCA and INF are not having any significant effect in explaining the changes in the agricultural sector output in Nigeria.

From the ECM results, the estimated coefficient for lending rate (LEN) $\{-14.679\}$ shows that there was a negative relationship between lending rate and agricultural sector output in Nigeria according to apriori expectations. This indicates that with an increase in lending rate in the 
economy, there is a significant decrease in agricultural output. This finding agrees with the results of Camillus (2019). Further the estimated coefficient for exchange rate (EXCH) $\{4.8431\}$ shows that there was a positive relationship between exchange rate and agricultural sector output in Nigeria. This relationship implies that an appreciation in exchange rates have a positive effect on the growth of earnings from agriculture. This finding corroborate the study conducted by (Adekunle \& Ndukwe, 2018) who found an evidence of exchange rate affecting the share of agriculture in gross domestic product positively. However, the finding contradicts with the study of (Muraya, 2014; Adongo, John, Zeph \& Muyima 2020) who obtained a negative influence of exchange rate on Kenya's agricultural output.

Furthermore, commercial bank credit to agriculture (CBCA) with an estimated coefficient of 9.4094 signified that there was a positive relationship between commercial bank credit to agriculture and agricultural sector output in Nigeria is in line with our apriori expectation. This positive relationship is in consonance with work of (Udeaja, \& Udoh, 2014) who found that commercial bank credit to finance agriculture has a direct impact on agricultural productivity. Lastly, the regression coefficient of inflation rate (INF) was -2.1221 . This implies that there was a negative relationship between inflation rate and agricultural sector output in Nigeria. Which means that price instability affects agriculture sector output negatively. Inflation discourages investment especially in the real sector as it causes a decline in the real return on investment. One of the major channels through which inflation affects agricultural investment is the increase in the price of agricultural inputs which reduces profitability. The findings is in line with Onwuka (2017).

\subsection{Conclusion and Recommendation}

The study investigated the relationship between financial sector liberalization and agricultural sector output in Nigeria. Using the unit root test, correlation analysis, Johansen cointegration test and the error correction model to analyze the data, the study reveals a significant long run relationship between financial sector liberalization and agricultural sector output. From the results of the ECM, the study concluded that lending rate and inflation rate have a negative relationship on agricultural sector output while exchange rate and commercial bank credit to agriculture have positive relationship on agricultural sector output. From the results of the analyses and the observations obtained, we can conclude that exchange rate and commercial bank credit to agriculture has a relatively stronger influence than other financial sector liberalization variables on the Nigerian agricultural sector output. The paper recommends that government and policy makers 
in Nigerian should initial policies that will boost investments in the agricultural sector through direct provision of credits to agriculturist and banks should also lend at a very low and subsidized interest rate to enable farmers' access agricultural loans that will boost agricultural productivity in the economy.

\section{References}

Adekunle, W., \& Ndukwe, C. I. (2018). The Impact of Exchange Rate Dynamics on Agricultural Output Performance in Nigeria. SSRN Electronic Journal. https://doi.org/10.2139/ssrn.3214757

Camillus, O. K. (2019). Causal relationship between financial sector liberalization and agricultural sector output in Nigeria. International Journal of Education and Social Science Research. 2(2), 26-42.

Camillus, O. K. (2019). Financial deepening and agricultural sector output in Nigeria. International Journal of Advanced Educational Research. 4(2), 1-9.

Central Bank of Nigeria (2004). Annual Reports and Statement of Accounts, December, 2004.

Central Bank of Nigeria (2020). Statistical Bulletin.

Ehinomen, C. \& Akorah, C.C. (2012). The impact of monetary policy on agricultural development in Nigeria (1970-2010). IOSR Journal of Humanities and Social Science, 5 (5), 13-25.

Engle, R F., \& Granger, C. (1987). Cointegration and Error Correction: representation, estimation and testing. Econometrica, 55(9), 251-276.

Francis, C., \& Kallummal, G. (2009). Sustainable Agriculture: An Overview. in C.A. Francis, C.B. Flora, and L.D. King (eds.), Sustainable Agriculture in Temperate Zones, New York, NY: Wiley, pp. 112.

Kisaka, S. E., Adhiambo, O. C., Ndege D. M. \& Muin, A. K. (2015). The Effect of Financial Deepening on the Performance of banks. Research Journal of Finance and Accounting. 6 (10), 20-35.

McKinnon, R.I. (1973). Money and Capital in Economic Development. Washington, DC: Brookings Institution.

Muraya, B. W. (2014). Determinants of Agricultural Productivity in Kenya. Review of Development Finance, 4(2), 115-125

NBS (2020). Nigeria Poverty Profile. National Bureau of Statistics. 
Oteng-Abaiye, E. F., Yusuf, H., \& Ussif, A. (2019). Empirical evidence on financial development and agricultural output in Nigeria

Onwumere, J.U.J., Okoro, O.O., \& Imo, G. I., (2012). The impact of interest rate liberalization on savings and investment: Evidence from Nigeria. Research Journal of Finance and Accounting. 3(10), 4553.

Onwuka, I.O. (2017). Reversing Nigeria's Food Import Dependency-Agricultural Transformation. Agricultural Development, 2 (1), 7-17.

Onoja, J.J. (2017). Financial sector development and agricultural productivity. Master's Thses. 238.

Okuma, E.G. (2019). The Financial Systems Role in Resource Mobilization and investment: An Analysis of Financial Deepening in Nigeria's Financial Sector.

Quartey, P., Udry, C., Al-hassan, S., \& Seshie, H. (2012). Agricultural financing and credit constraints: the role of middlemen in marketing and credit outcomes in Ghana. Working paper 12/0160. International Growth Centre. London.

Shaw, E. (1973). Financial Deepening in Economic Development. New York: Oxford University Press.

Tobin, J. \& Stingtlz, W.C., (1989). Financial intermediaries and the effectiveness of monetary controls. American Economic Reviews. Paper and Proceedings of 75th Annual Meeting of the American Economic Association, 53.

Tilakaratna., S (1996). Credit schemes for the rural poor: Some conclusions and lessons from practice. Issues in Development Discussion Paper.

Udeaja, E. A. \& Udoh, E. A. (2014). Effect of monetary policy on agricultural sector in Nigeria. Economic and Financial Review. 52(2), 37-71.

Uniamikogbo S. O. \& Enoma, A. I. (2001). The Impact of Monetary Policy on Manufacturing Sector in Nigeria: an Empirical Analysis. The Nigerian Journal of Economic and Financial Review. 3 (2), $37-45$. 